\title{
From Neglect to Nexus: Examining the Place of Educational History in Teacher Education
}

\author{
De la negligencia a la conexión: examen del \\ lugar de la historia educativa en \\ la educación del profesor
}

\section{Un examen du rôle de l'histoire de l'éducation dans les programmes de formation des enseignants : négligence ou noyau}

\section{Theodore Christou}

University of New Brunswick

\section{Alan Sears}

University of New Brunswick

\begin{abstract}
In faculties of education across North America, the so-called foundations of education are in crisis. Pressure to shorten teacher education programs and to focus on developing the instrumental skills of new teachers has resulted in courses in philosophy, history, sociology, anthropology, and psychology being moved from the core of teacher education to the periphery. This paper describes the decline of history in teacher education using the Faculty of Education at Queen's University as a case study. We contend this decline occurred more by systematic neglect of history's value in professional education than by overt attack on its position as one of "the foundations" of the field. We go on to argue that history, properly taught, has the potential to provide a powerful nexus to teacher education programs helping new teachers locate themselves and individualize their personal beliefs in relation to the vast body of professional knowledge that is circulated and recycled about policy and practice.
\end{abstract}

Key words: teacher education; history of education; educational history; foundations. 


\section{RESUMEN}

En las facultades de educación de Norteamérica, los fundamentos de la educación están en crisis. La presión para reducir los programas de educación del profesorado y centrarse en el desarrollo de las habilidades instrumentales de los nuevos profesores ha llevado a la filosofía, la historia, la sociología, la antropología, y la psicología de ser el centro neurálgico de educación del profesor, a la periferia. Este artículo describe la reducción de la historia en la educación del profesor en la Facultad de Educación en la Universidad de la Queen's como un estudio de caso. Sostenemos que esta reducción se produjo más por el abandono sistemático del valor de la historia en la educación profesional que por el ataque abierto a su posición como uno de "los fundamentos" del campo. Se argumenta cómo la historia, correctamente enseñada, posee un gran potencial para proporcionar nexos con los programas de formación docenteque pueden ayudar a los nuevos maestros a ubicar e individualizar sus creencias personales en relación con el vasto cuerpo de conocimiento profesional que se distribuye y se recicla sobre la política y la práctica.

Descriptores: educación de profesor; historia de educación; historia educativa; fundamentos.

\section{RÉSUMÉ}

Dans les facultés d'éducation partout en Amérique du nord, les soi-disant fondements de l'éducation sont en crise. Les pressions exercées sur les facultés de raccourcir les programmes de formation et de se centrer sur le développement d'habiletés instrumentales ont mené à la marginalisation des cours comme la philosophie, l'histoire, la sociologie, l'anthropologie et la psychologie. Dans cet article, nous décrivons le déclin de l'histoire dans la formation des enseignants en utilisant la faculté d'éducation de l'université Queens comme étude de cas. Nous postulons que ce déclin s'est produit à cause d'une négligence systématique de la valeur de l'histoire dans la formation professionnelle et non pas à cause d'une attaque manifeste de son statut comme un des "fondements " $d u$ domaine. Nous prétendons que l'histoire, enseignée convenablement, a le potentiel d'être le noyau des programmes de formation des enseignants, permettant aux enseignants débutants de se retrouver et de personnaliser leurs croyances vis-àvis le corpus énorme de connaissances professionnelles circulé et recyclé à propos de la politique et de la pratique.

Mots clés : formation des enseignants ; I'histoire de l'éducation ; histoire educative ; fondements.

One of the disturbing characteristics of the curriculum field is its lack of historical perspective. New breakthroughs are solemnly proclaimed when in fact they represent minor modifications of early proposals, and, conversely, anachronistic dogmas and doctrines maintain a currency and uncritical acceptance far beyond their present merit

—Herbert M. Kliebard (1987, p. 153)

\section{Introduction}

Curgeons and physicians cannot practice medicine without some founda$\checkmark$ tional understanding of the history of the profession. Judges' verdicts are inevitably informed by the common law decisions past colleagues have made. Regardless of discipline, an assumption underlying undergraduate survey courses is that no original analysis and perspective is possible without an awareness of past analyses and perspectives. This logic goes beyond the old adage that we must know where we came from to know where we are going; ignorance of history's articulations dooms us to 
"reinvent the wheel" without ever rolling past old debates and problems. This problem is well summarized by the title of a recent book that characterizes the history of educational reform as The Same Thing Over and Over (Hess, 2010).

Further, we are unable to fully know what is - relative to our own systems of evolution and in comparison to other systems - without knowledge of what was and in relation to what might have been. Even if history does not, as is popularly thought, repeat itself because human social interactions are context-dependent and-determined, historical antecedents represent possibilities of action and thought that educators can adapt, interpret, and attempt to apply to the unique contexts in which they work (Kliebard, 1992). These possibilities are, according to John Dewey, intellectual instrumentalities that operate as the sources of reflective practice and professional inquiry and observation, not rules and recipes of conduct (Dewey, 1929).

In its fullest sense this sort of reflective practice extends well beyond the work of individual practitioners to include their engagement in shaping the profession itself. Barton and Levstik (2004) argue that one reason for studying history is to foster informed deliberation about the common good and every profession is enhanced when that occurs both within the profession itself and in the broader social and political context. Educators are more than classroom instructors, they are also, or should be, "civic professionals" (Kennedy, 2005), important resources in the public quest for better educational policies and systems.

Yet, across educational jurisdictions in Canada, the so-called foundations of education are in crisis (Christou, 2009). Foundations subjects have over the past century come to represent an interdisciplinary study of contemporary social or psychological aspects of teaching and learning. Philosophy, history, sociology, anthropology, and psychology have been depicted as foundational in undergraduate teacher education.

Teacher candidates embark on a professional journey with a peculiar case of institutionally-induced amnesia. They have not developed a systematic understanding of the traditions that can provide them with a more comprehensive perspective of educational issues. This perspective can help new teachers locate themselves and individualize their personal beliefs in relation to the vast body of professional knowledge that is circulated and recycled about pedagogy.

Further, reflective practice, defined in this paper as the demonstration of critical and creative thinking in action, requires that educators critique their actions and the processes nested in the educational systems in which they are enmeshed (Schön, 1983; Schön, 1987; Grimmett, MacKinnon, et al., 1990; MacKinnon and Erickson, 1992; Zeichner, 1992). Unless human artistry in instruction is proven useless, we maintain hope that teachers can further the aims and achievements of education by engaging in critical reflection, doubting, and acting in ways that are novel and contextually necessary. Without educational history, a source of nearly infinite pedagogical experiences and resources, we educators are prone to being spun like Ixion upon a wheel in Hades, eternally revolving and resuming past positions. The tethers of our personal learning experiences and of those who surround us will bind us.

In this essay, prompted by the concerns noted above, we present three sections; these sections are interrelated arguments integrating the past, present, and future of 
educational history within university faculties of education. The first section considers the decline of educational history within teacher education curricula over the past century by examining the program of study at Queen's University as an indicative case. The second section postulates that our contemporary educational context is a new progressive age, and relates the blinding pursuit of technology in the classroom to the themes of progressive education. In the first wave of progressive education in Canada, the humanities were marginalized at the expense of new ideas and courses that seemingly related more closely to the social and technological realities of modern life; the voices of humanist critiques from the 1930s and 1940s are juxtaposed with the contemporary concerns for accountability and modernity. The third section argues that the history of education must be revisioned, or, seen otherwise. Its aims in education today must be seen as vital to the development of a critical and intelligent citizenry.

This paper thus seeks to integrate historical and subjective argumentation and analysis. Implications are drawn with regards to both history and civics education, but we are primarily concerned here with the marginalization of history as a discipline within teacher education. This discussion that follows is one section of a broader, national, and historical examination of contemporary teacher education in Canada.

\section{History's Marginalization: A Brief Look at Queen's University}

We begin with the assertion that history of education as a discipline of study is presently neglected in Ontario teacher education (Christou, 2010; 2009). The withering of educational history as a mandatory subject in teacher education has been slow and silent - no university administrator has stood at the pulpit and said anything to the effect that "the history of education shall die, and I shall be its executioner." It is vital to remember that educational history has not always been absent from teacher education in Ontario. A survey of the course calendars for Queen's University's Faculty of Education can serve as an indicative example. From 1907 to 1920, the history of education and educational systems was a mandatory component of the program. In 1921 Ontario closed the Faculties of Education at Queen's and the University of Toronto, centralizing high school teacher education in the province for the subsequent thirtythree years in the Ontario College of Education (OCE) at the University of Toronto. With the reopening of Queen's Faculty of Education, which began courses in 1968, the subject of educational history first appears in the course calendar as an integrated element of the "foundations" classes. These foundations classes were mandatory, cross-disciplinary courses of study. By the 1995-1996 school year, neither history nor foundations courses are to be found in the calendars. At present, both courses are advertised as half-credit electives.

Nineteen-oh-seven marked the foundation of the Faculty of Education at Queen's University, which replaced the Ontario Normal College (Queen's University, 1907). Its purpose was the "practical and theoretical training of teachers of the Public and High School work of Ontario” (Queen's University, 1907). The same year, a Faculty 
of Education was set up at the University of Toronto; these were the only Faculties in the province.

The General Course of studies for teacher candidates had three parts - Part I comprised the study of "History of Education and Educational Systems, the Principles of Education, Elementary and Applied Psychology, School Administration and School Law, School Management, General Method, and special Methods" (Queen's University, 1907). Parts II and III of the General Course corresponded to contentarea (Curriculum) and Practice Teaching (and Observation), respectively (Queen's University, 1907).

Part I of the general course of study, as described by the academic calendar, was heavily weighted towards the academic study of disciplines that would ground teacher candidates in the philosophy and history of education. A look at the first section of the general course, "History of Education and Educational Systems," makes evident the emphasis on establishing a theoretical "foundation" upon which practical knowledge could be constructed:

Evolution of Education in Primitive Society. Oriental Education. Greek Life and Education. Roman Life and Education. Education in Middle Ages. Scholasticism and the Rise of the Universities. Renaissance and the Rise of Humanism. Reformation and Counter-Reformation. Realism and Science in Education. Education according to Nature. Psychological and Sociological Aspects of Education. Education in Germany, Great Britain, United States, and Ontario (Queen's University, 1907)

The "Advanced Course" is described as "the General Course repeated, with a detailed study of special periods and movements" (Queen's University, 1907). It is worthy of note that the academic aspects of the General course are the first listed in the calendar (Part I) and the ones described in greatest detail. The theoretical component of teacher education was central to the program, as described by the academic calendar.

The model set in place in 1907 remained intact until the 1917-1918 school year when Part I of the general and advanced courses were reduced in scope to include only the History of Education, the Science of Education, and School Organization and Management" (Queen's University, 1917). The General and Specific Methods portions were moved to Part II of the course, in line with the content-area and curriculum courses. This served to increase the academic scope of Part I of the program, the basis and foundation of the teacher education program (Queen's University, 1917).

In 1919-1920, the first part of the general and advanced courses was reorganized. What is apparent from the academic calendar is a thrust to increase the rigour of the historical component of study, with an emphasis on primary sources. Previous calendars had suggested the use of textbooks, but in 1919 it is recommended that students interact with primary texts in the history of education:

Educational Classics. - The study in class of selected portions of the following: Plato, Republic, Books I-IV; Quintilian, De Oratore; Vergerius, De Ingenuis 
Moribus; Milton, Tractate on Education; Locke, Some Thoughts concerning Education; Rousseau, Emile; Pestalozzi, How Gertrude Teaches Her Children; Herbart, The Science of Education; Froebel, The Education of Man; Spencer, Education-Intellectual, Moral and Physical; Dewey, Democracy and Education (Queen's University, 1919).

In 1920 the Department of Education reorganized teacher education in the province and centralized study at the Ontario College of Education in Toronto. The Faculty in Kingston was closed for nearly half a century.

In 1968, when the Ontario government re-established the "faculty of education" at Queen's as McArthur College of Education, the "Foundations of Education" resumed their predominant position in the program of study (Queen's University, 1968). A "Point System" was put in place in order to "implement the double objectives of (1) providing individualized study plans for candidates and (2) ensuring that their selections satisfy graduation and certification requirements" (Queen's University, 1968). According to the new system, the "Foundations" are the first of five components listed in the curriculum, and the area of study assigned the most time in the schedule (eight to ten hours weekly) and value (forty points), as measured by the point system (Queen's University, 1968).

Of significance are the notes following the table posted above; they explain that the Educational Foundations course was the only one uniformly required of all teacher candidates. Justification for this policy was described as follows:

Properly regarded, the several studies comprising Education Foundations have an important place in the preparation of professional educators. It is not enough for the practitioner to master the skills related to his work; he must also develop a conceptual framework for proper understanding and criticism of both his work and its general educational setting. These options help to strengthen the professional competence of teacher candidates by providing them with the distinctive insights and analytical perspectives peculiar to each discipline (Queen's University, 1968).

In 1968, it was understood that "Foundations" courses, particularly the study of History and Philosophy of Education, could "provide a realistic initiation into some of the significant problems of administrative and professional practice" (Queen's University, 1968). The calendar hints that the method of instruction in this course involved, in part, the case study approach as a means of engaging faculty and students in examination of educational issues and problems (Queen's University, 1968). The model of teacher education that was established in 1968 at Queen's remained effectively unchanged at the school until 1974 (Queen's University, 1970; Queen's University, 1971; Queen's University, 1972; Queen's University, 1973).

The 1974-1975 academic calendar from the Faculty of Education describes important changes to teacher education at Queen's, insofar as the study of foundations courses is concerned. The point system was replaced by course credits that would be 
counted on a credit hour basis. Each area of the teacher education curriculum carried a value of six credit hours, while options in the foundations were weighted at between four-eight credit hours (Queen's University, 1974). To satisfy program requirements, candidates needed to acquire thirty-four credit hours, twelve of which had to be gained studying the "Educational Foundations" (Queen's University, 1974).

Of particular importance is the favourable shift in credit value assigned to the study of Curriculum. It is the first time that the academic calendar shows that content-area study had equal value to that of the "foundations." Teacher candidates were to choose two of "Contemporary Issues and Human Problems, History and Comparative Education, Philosophy, Psychology, [and] Sociology” and earn 1.5 credits for their study (Queen's University, 1974). Teacher candidates also chose two content-area topics to study (Language, Mathematics, Science, etc.) for equal credit. The equal valuation of "Foundational Studies" and "Curriculum" lasted until 1979, when, as described in the 1979-1980 Calendar, Curriculum study was given greater weight than that assigned to any other component of the program:

\begin{tabular}{|l|l|}
\hline PROGRAM COMPONENTS & CREDITS \\
\hline Foundational Studies & 1.5 course credit \\
\hline Curriculum & 2.0 course credit \\
\hline Professional Skills & 0.5 course credit \\
\hline Practicum & 0.5 course credit \\
\hline Special Studies & 0.5 course credit \\
\hline \hline TOTAL REOUIREMENT & 5.0 course credit \\
\hline
\end{tabular}

(Queen's University, 1979)

The program model noted in the table above was essentially unchanged until 1995 (Queen's University, 1980; Queen's University, 1981; Queen's University, 1983; Queen's University, 1985; Queen's University, 1991; Queen's University, 1993; Queen's University, 1994).

The 1995-1996 academic calendar is notable because the term "foundations" is entirely absent; the language and structure of the teacher education program that had been in place since the Faculty of Education's re-establishment in 1968 is dramatically altered. The calendar shows that the foundations have been split into two areas, Educational Studies and Learning and Development in Education (LERN) and Social and Contextual Studies in Education (SOCS) (Queen's University, 1995). "LERN" courses are "concerned with sociological, psychological, historical, philosophical, aesthetic, political, and institutional studies in education with a focus on the individual learner." (Queen's University, 1995). "SOCS” courses deal with "sociological, psychological, historical, philosophical, aesthetic, political, and institutional studies in education with a focus on the broader contextual aspects of education and schooling" (Queen's University, 1995). This splitting of foundations into two areas of interdisciplinary study, psychological and social, is reminiscent of the model set out 
by Columbia University's Teachers College (which actually coined the term "foundations" in association with this movement), as described above.

While the following year's academic calendar describes no alterations to the program structure or the description of courses, there is an important change in the admission criteria required for applicants in preparation for Primary-Junior division work. It had been policy to inform teacher candidates that prerequisite academic study had to involve:

At least one full-year university course (or two half-year courses) in each of 1) psychology, 2) language or linguistics, 3) arts (visual arts, performing arts, or music) or equivalent (equivalency may be granted for conservatory qualification in music, extensive production experience in drama, etc.), 4) social studies (history, geography, political science, sociology, or anthropology). In addition candidates must have completed Grade 12 advanced level or Ontario Academic Credit mathematics, or a university half credit or semester course from a mathematics department (Queen's University, 1995).

In the 1996-1997 calendar, academic prerequisites are only a half-year university course in "psychology, sociology or anthropology" (Queen’s University, 1996, my italics).

It is more difficult to find the study of history and philosophy of education in the 1997-1998 Faculty of Education academic calendar. "SOCS" and "LERN" courses are no longer listed and the term "foundations" has still not resurfaced. A new course, "Educational Studies," valued at 0.5 credits, "concerned with sociological, psychological, historical, legal, philosophical, aesthetic, political, and institutional aspects of education and schooling" makes its first appearance (Queen's University, 1997). A second course of equal value, "Critical Issues and Policies," is introduced under the canopy of "Professional Studies" with a mandate of introducing:

Issues and policies that are critical for beginning and experienced teachers. It invites candidates to build on their experiences in classrooms and associate schools, to begin to learn about their legal rights and responsibilities as teachers, to begin to learn about adapting instruction for exceptional learners, and to begin to learn about equity issues they will face in schools (Queen's University, 1997).

The changes to the program described here seem to represent a greater integration of practice and theory but they mark a demonstrable shift in program priorities. The course description makes clear that practical knowledge is not constructed on the "foundation" of theory. To the contrary, the Critical Issues and Policies course, a social engagement geared towards critical thinking, will be based on contemporary and personal classroom experience. In 1997, the academic calendar shows that the definition of a foundation has been flipped on its head. History and philosophy of education only exist insofar as they are capable of assisting the process of 
"constructing and documenting professional knowledge acquired by experience" (Queen's University, 1997).

There are few documented changes to the program structure until 2001, when a half course in "Foundations" is re-instituted into the curriculum of the Faculty of Education at Queen's (Queen's University, 2001). At present, that half-course is present in the calendar as an elective (Queen's University, 2006). The Professional Studies component of the program is worth 1.0 credit and has been expanded to include three parts: "Critical Issues and Policies, Concepts in Teaching and Learning, [and] Theory and Professional Practice” (Queen's University, 2006). Unless a teacher candidate elects to add a course from the foundations to their schedule, it is in the Professional Studies course that critical thinking and theoretical components necessary to reflective practice will be addressed. Curriculum, or content-area study is valued at 2.5 credits - half of the total requirement (Queen's University, 2006).

This brief case study of a hundred years of teacher education in Kingston is employed to demonstrate how, from the perspective of documentary evidence found in the university archives, muted and silenced the history of education's marginalization has been. This trend, which is visible in the micro-sense in the Queen's context, is broad and sweeping. History's marginalization in teacher education is a veritable crisis for the discipline, which is to say nothing of the perils of training rather than broadly educating teachers. Recently, the University of Toronto's graduate program housed at the Ontario Institute for Studies in Education has ceased to accept new enrolments, and it is prognosticated that the program shall be axed. This has been the beacon program in the Canadian context, and its closure could have epic repercussions.

Teacher education seems determined to be on the cutting edge of whatever new program or technology appears. This is most evident in the near obsession with purchasing SMART Boards, which are interactive white boards, for every classroom. The arguments in favour of integrating these interactive white boards into teacher education is reasoned that public school principals in Ontario school districts are supportive of new technologies, and teacher candidates will be better prepared to teach if they are familiar with the media. Ellen Rose (2000) demonstrates this shift in teacher role in the general sense and illustrates it with particular attention to the province of New Brunswick, where in many instances the pursuit of technological integration in education has transformed technology from a means to an end in itself. This is well illustrated by the recently adopted " $21^{\text {st }}$ Century Standards of Practice for Beginning Teachers in New Brunswick” (Province of New Brunswick, n.d.), which has been endorsed by all teacher education programs in the province. The document has a section titled "Professional Knowledge and Understanding," which says nothing about knowledge of the history of the teaching profession or education more generally but does mandate that:

Teachers know and understand student-centred pedagogies and how to integrate current and emerging information communication technologies (ICT) to meet the learning needs of $21^{\text {st }}$ Century students in an inclusive education setting. 
While it is reasonable to agree that this might be the case, various dilemmas arise from the assumed position. First, a point already discussed, teacher education must educate, not train. Second, teacher education will transform itself into an essentially redundant enterprise if it prepares teachers to do things that they will inevitably learn anyway by working. Third, teacher educators must be leaders in education, as opposed to followers. Education will always be a half step, at the least, behind technological advancement. At the present rate of technological progress, what is current today will be soon thereafter obsolete, or dated. Teacher education must focus on larger questions of education in human life, such as those that history frames and examines.

\section{A New Progressive Age in Education: Humanist Decline in Education}

Perhaps tacitly, we are caught in the flow of a new progressive movement in education. In the Ontario context, the first progressive education movement emerged post-World War One, when rapid industrialization, immigration, urbanization, and technological advancement transformed the province's social and economic foundations. Education, then, as now, was seen as being out of touch with the changing and ever-evolving realities of life. Education, then, as now, was seen as a panacea, which could be a force in preparing future generations for the realities of a new and modern world. A new, progressive education, was required for a new, progressive world. Space here will not permit a lengthy analysis of the early twentieth century debate in the academy concerning the development of disciplines of study, the repositioning of the humanities subjects therein, or the notion of a "liberal project" as a force in modern life and ideas (See, for example, Sears, 2003; Menand, 2010; Nussbaum, 2010).

Then, as is the case today, the entrenched curriculum came under attack. The humanities and the classics, including Latin and Greek, were depicted as preparing students for a world now past. They had to demonstrate their utility in the modern context of schooling, or they needed to be marginalized in favour of subjects like the newly-devised social studies, which concerned contemporary social and cultural life. Advocates for the humanities bitterly fought back, arguing that it is the humanities subjects that are most vital, for as all things change, the study of history and literature steadies us. They became entangled in a passionate but, ultimately, futile struggle to relate schools to contemporary life.

If social conditions were, indeed, ever evolving, Ontario's humanists in the 1930s and 1940s argued that it was folly to attempt to keep up with these changes. Henry Bowers, a teacher from Fergus, Ontario, characterized progressive education as a "millipeducation." The title of his article, "Guesswork," highlighted what he called the fundamentally "contradictory tendencies" embedded in progressivist, modern thought. Progressive education was, for Bowers, "a great millipede, the legs of which reserve to themselves the right to independent action. Some move forward; others, with delightful contrariety, insist that backward is forward" (Bowers, 1939, p. 97).

In the same issue of The School, Evangeline Lewis from the Mount Allison School for Girls blamed progressivist ideas for the modern concern for specialization of study 
(Lewis, 1939, p. 101). The traditional humanistic curriculum was, by contrast, broad and encyclopedic. It enabled exploration of the relationships among personal, contextual, and eternal phenomena. The classics remained classic because of their eternal value, whereas the future was contingent, mutable, and unpredictable. Predicated on that same argument, Bowers presented his most derisive characterization of progressivist millipeducation:

"Gressives" they are, no doubt; but which is "pro-" and which "retro-"? Certain legs agree that lateral movement is desirable, but half of these maintain that the true path is on the right, while the others are equally positive that it lies to the left. Indeed, there are wistful legs that find on solid earth no rest for the soles of their feet and sigh for the wings of a dove (Bowers, 1939, p. 97).

Bowers' depiction of progressivist ideas stands out for its sarcasm and originality, but more commonly progressive education was slandered as being overly concerned with "fads and frills" (The Canadian School Journal, 1934, p. 43).

These humanist critics maintained that the concerns of progressivists would change and sway ephemerally and subjectively, whereas more academic subjects were lasting and substantial (The Canadian School Journal, 1934, p. 43). Citing a fortyfive-year old article that had appeared in the New York Evening Post, a 1934 editorial in The School equated the progressivist concerns for school reform with the passing of crazes, one always supplanting some other:

The history of education in this country for the past fifty years has been a history of crazes - the method craze, the object-lesson craze, the illustration craze, the 'memory-gem' craze, the civics craze - calling upon children of eight to ten for information as to custom-houses, post-offices, city councils, governors, and legislators - the story-telling craze, the phonics craze, the word-method craze, the drawing and music craze, beside the craze for letters and business forms, picture study and physics. Now arrives manual training (The School, 1934, p. 370).

The 1937 and 1938 revisions to Ontario's Programme of Studies were seen by many humanists to be another example of what the above editorial called mere "fluctuations, shiftings, and tinkerings" (The School, 1934, p. 370). Speaking two years after the first curriculum revisions were published, the Principal of the normal school in London, C. E. Mark, felt he spoke for a great many educationists when he expressed doubt about the revisions' value and substance (Mark, 1940, p. 564). Critics of the progressivist craze for reform were fearful, he explained, of being labelled as ultraconservatives; the swing toward progressive education in the province, however, was too extreme and dramatic to be sustainable:

Progress is best achieved, not by repudiation of the past, but by a reconstruction of the past. Some of the best thought of the ages has been built into our 
educational theory, and practices worthy of that theory have been based in the main on principles that are eternal. And so, young teacher, give ear to the first note of warning, to view that past with a full sense of indebtedness and gratitude, and to beware of turning too far to an extreme just because it is new and different (p. 564).

Progressivists, for Mark, were akin to petulant and overly excitable youth.

Professor L. J. Bondy lamented that "one of the first results of the progress has been the passing of the classical languages; Greek already buried and Latin with one foot in the grave" (Bondy, 1938, p. 120). Bondy poked fun at the lofty claims of progressivists who believed the schools should address all of society's ills and, noting different possible destinations for progress, challenged the advocates for progressive education to define its aims with greater accuracy (p. 120). If the humanists' voices in the educational literature were losing their prominence, they refused to go silently. W. H. Fyfe, Principal of Queen's University, blamed certain progressivists for the Depression, and accused them of being inspired by the ignoble motive of producing fodder to work in factories. In his opinion, they cared not for "slow mental growth but training for trade or industry. It is a short-cut which has landed us in the Slough of Despond" (Fyfe, 1934, p. 653).

R. B. Liddy, Professor of Psychology at the University of Western Ontario felt that the pendulum of progressivist reform in Ontario's schools had swung too far and overly relegated academic content: "We must not lose perspective when we recognize the need for a richer curriculum; and we must continue to emphasize the fact that the primary scholastic function is intellectual education. The chief emphasis of the school must be upon what the title of this paper designates, rather loosely perhaps, the making of the mind" (Liddy, 1934, p. 233). Intellectual progress, he concluded, founded on knowledge of the heritage of past human achievements and developed by the language and number arts, was the most valuable basis for curriculum construction.

In our own present situation, the history of education was dealt heavy blows from forces beginning in the progressive period, including the "accountability shift" in teacher education, which, since the 1980s represents a relatively recent need for disciplines to demonstrate proof that they are meritorious of space and time in program curricula (Bales, 2006). History of education has not proved to be immediately relevant to the needs of beginning teachers and, consequently, has fallen out of the utilitarian concerns associated with accountability bean counters. The historical and philosophical foundations of education are viewed by both teachers and principals as one of the least significant coursework requirements vis-à-vis their present job tasks (Levine, 2005). Datasets from Ontario are even scarcer, and scholars in this province often rely on American studies (American Educational Research Association, 2005). These have been proven relevant in relation to trends that show how reforms in curriculum, national testing, standards, accountability, parental choice, and system restructuring have followed similar lines in the United States and in Canada (Evans, 1987; Miller, 2002). 


\section{Revisioning History of Education}

Andy Hargreaves (2003, p. 7) calls for teaching to become a "grown-up profession" where teachers engage as thoughtful and critical agents who shape the profession rather than simply as technocratic implementers of current fads mandated by others. Indeed the literature is rife with laments about teaching's slow struggle to grow up as a profession in just this way (for example, Strike, 1993; Ungerleider, 1994; 2003; Hyslop-Margison and Sears, 2010). We believe the study of the history of the field is a critical component in the move away from technocratic and limited approaches to the profession toward more humanistic, open, and "grown-up" ones, and in this section will briefly set out some directions for a revisioning of the history of education consistent with that project.

First, scholars and teachers of the history of education must admit their own complicity in its demise. The decline of educational history as a key component of teacher education programs, which we cursorily outlined above, occurred at roughly the same time and in substantially the same manner as the decline of school history as a central component of public school curricula. We have written in detail elsewhere of the supplanting of history with a present focused, utilitarian, and generic approach to citizenship education rooted in social studies (Christou and Sears, 2010; Sears, 2011). Just as with the history of education, progressivist pressure for a more "useful" and "relevant" curriculum was a key factor in history's demise as a school subject. School history lacked a suitable defense in the face of its marginalization, in part, because what actually happened in history class was bad history badly taught.

Forty years ago, the most comprehensive study of history and civics education ever conducted in Canada found a "bland consensus version of history" (Hodgetts, 1968, p. 24) was being taught across the country. In her more recent examinations of history education in Australia and Canada, Anna Clark (2008, p. 114; 2009) discovered things were essentially the same. Students from across both countries told her they thought national history was important to know but that the history education they experienced was "excessively content-driven and teacher-focused" almost never allowing for the consideration of multiple perspectives or focused on developing deep understanding. Reports from around the world echo these findings with students claiming that in their history classes "debates are practically nonexistent" and teaching focuses "on memorization and repetition of teachers' explanations (through taking of class notes) and the contents of textbooks as the core of their history education experiences" (Valls, 2007, p. 164). To the extent to which the history of education in teacher education programs presented this kind of dry-as-dust, pacified history devoid of any relevance to students' lives, its demise in neither surprising nor regrettable.

While there is widespread evidence that history teaching across much of the world has followed the patterns described above, the distortion often perpetrated by "progressive" advocates of more useful and relevant approaches has two parts: a) the generalization that history is necessarily that way, and b) the implication that more utilitarian approaches are never that way. Both parts of this claim are false. As Osborne (2011) illustrates, there are and always have been plenty of counter-examples of 
history teachers who have involved students in substantial and relevant historical study, including attention to important substantive and procedural concepts in the field. As well, scholars and teachers who advocate developing students' capacities for historical thinking are committed to engaging students as active agents in understanding not only historical materials but also the processes and deliberations that shape those materials. Virtually all see this as an enterprise designed to, among other things, "promote reasoned judgment" (Barton and Levstik, 2004, p. 36). Reshaping the history of education to do this will mean, among other things: a) connecting it to the lives, interests and professional concerns of beginning and practicing teachers, b) engaging students in the construction of educational history, and c) involving them in the conflicts inherent in the discipline of history generally and the history of education in particular.

All students come to the history of education having lived some of that history themselves. It seems to us an engaging way into the discipline is to recognize that connection and use it to build an interest in the broader field. For example, one of us (Sears) began school in 1960 just as the work of Jerome Bruner (1960) and others was transforming North American education around the so-called "structure of the disciplines" approach to teaching and learning. He remembers junior high textbooks with "New Math" as part of the title (and wondering what was particularly new about it), and high school teachers attempting to engage classes in disciplinary practices such as reading and analyzing historical documents or writing poetry. The professor who taught the social studies methods course during his initial teacher education in the mid-1970s had just completed a doctorate at Carnegie Mellon University working with Edwin Fenton (1967) who literally wrote the book on the "New Social Studies." Consequently, Sears entered teaching with a deep commitment to engage students in doing history and in his early years saw the demise of the structure of the discipline reforms as curricula and materials turned away from them and in new directions. Sears lived through and experienced a major movement in the history of education but never had the opportunity in his own undergraduate teacher education, or during his Master's degree for that matter, to make connections between his own lived experience and the themes and issues being explored by educational historians. Once he began to see those connections for himself, the subject took on much more salience for him.

Most of the students we see in our undergraduate teacher education programs today entered school in the early to mid-1990s and lived through a cycle of what has been described as neo-liberal or conservative reform including an incredible rise in accountability measures, which include standardized testing and the concomitant impacts on curricula and teaching. This exemplifies what Ravitich (2010) describes as the often overweening focus on literacy, mathematics, and technology vis-à-vis the humanities and the arts.

Our students' experiences in school provide rich opportunities to illustrate recent trends in the history of education, and we argue that it is essential to begin instruction of historical subjects by asking students to tell their own stories. We do not contend that the study of the history of education should be limited to eras and phenomena 
directly experienced by students but, rather, that we should meet them where they are in order to take them to new places. It is our stories, personal and collective, that imbue history with human meanings and enable us to forge connections with each other and with the past; as Christou (2010) noted: "Bereft of the stories that imbue history with narratives exploring who we are on this earth, and overburdened with theoretical frameworks that impose meaning on the past from above, educational history is unrecognizable as a humanistic study" (p. 50).

Another way to establish connections between our students and the history of education is to help them to see its relevance to their own teaching practice. While it is essential for teachers and teacher candidates to engage as critical practitioners and as shapers of education, and despite our conviction that a deep and complex understanding of educational history is essential to this aim, our undergraduate students often do not buy that argument. They are very focused on figuring out what and how to teach in the narrow context of their own classroom. Educational history is, we argue, a study of great relevance to classroom teachers. School subjects have histories of their own, and understanding the history and development of the subjects taught in schools builds the kind of critical understanding of subject matter generally advocated in curricula around the world. Writing about mathematics, for example, Jankvist (2009) contends that history has a role to play both as "a tool for the actual learning and teaching of mathematics' and 'as a goal in itself'" (p. 237).

As a tool, history can demonstrate to students that the concepts and processes they struggle to learn were not arrived at quickly and easily by mathematicians either, but that these took years to work out. An understanding of the fluid and shifting nature of particular topics can help students cognitively as they develop their own understandings of the subject matter. As a goal, history helps students to understand the contextual situation of the discipline. Students will come to understand math as:

A discipline that has undergone an evolution and is not something that has arisen out of thin air; that human beings have taken part in its evolution; that mathematics has evolved through many different cultures throughout its history and that these cultures have had an influence on the shaping of mathematics and vice-versa; or that the evolution is driven by internal and external forces (Jankvist, p. 239).

Howe (2009) takes up the same theme with regard to teaching science. He argues that contemporary science curricula call for students to develop an understanding of the nature of science as a discipline. This is important because it helps "students develop their understanding so they will become critical consumers of the very scientific knowledge that increasingly impacts their daily lives" (p. 397). He contends that teaching the history of science is the key way to achieve this as it fosters an understanding that "there are historical, cultural, and social influences on the practice of science" (p. 397). Howe goes on to suggest that students study critical episodes in the history of science engaging with questions such as: "How was the scientist's work 
influenced by the culture in which he/she operated? What ramifications may his/her conclusions have on sociological or political policy? Did any issues of ethics or values come into play with the historical episode?” (p. 401).

\section{Conclusion}

Demonstrating to education students that knowledge of the history of the discipline they have chosen to teach and its evolution as a school subject can improve their abilities to teach the subject comprehensively and effectively has great potential for enhancing their openness to engaging enthusiastically in the study of the history of education. Again, we are not arguing that the study of the history of education ought to be limited to this but it is a great place to begin. We suspect, for example, as young teachers come to understand and teach that the development of their discipline as a school subject has been contested and fluid they will come to see themselves as potential shapers of the field for the future.

In addition to developing connections between students and subject matter, we believe engaging them in the construction of the history of education is also an effective tool in enhancing student interest in and understanding of the discipline. There is a vast and growing literature on the centrality of engagement with disciplinary concepts and processes in fostering historical mindedness which we do not have space to address here (See, for example, Lévesque, 2008; Levstik and Baton, 2008; Clark, 2011). In a teacher education context, however, we agree with Sandwell (2011) who argues that history is best conceptualized as a verb; consequently, we need to do history in order to understand it.

To that end, we have engaged elementary education students at the university where we teach in writing a history of science education in our province. These students are taking a course titled Learning to Learn About Teaching Social Studies and Science. Many come to the course with little or no university background in social studies or science so we decided to focus on developing some understanding of the nature of those disciplines or areas as a base on which students could build pedagogical approaches for their own teaching. The major assignment of the course is to write a history of science education in the province for one of the decades of the twentieth century. Working in groups, students use archival, government, oral, and secondary sources to construct the history of their decade. The students are doing history to learn about science and in the process developing a much more complex understanding of the nature of both as disciplines.

Finally, we believe immersing students in the conflicts that characterize the discipline enhances engagement with history. As demonstrated above, school history is most often present as a grand narrative of events and personalities devoid of alternative views or conflicts. Unfortunately, university history courses, including those in the history of education are often the same. History as a disciplinary enterprise, on the other hand, is all about developing diverse and contested accounts of the past. Engle (1986) explores this dichotomy. 
For reasons I have never fully understood, most history professors completely change their colors when they step out of their role as research scholars and take on the mantle of 'herr' professor. As scholars they hold truth in great tenuousness; they are not all of one mind; their disciplines are hotbeds of controversy; they are forever correcting one another's errors. But once they have laid aside their research eyeshades and donned their teaching robes, they become authorities whose mission is considered to be the transmission of their superior knowledge to students (p. 21)

There is clear evidence that school students enjoy history more and engage with it much more deeply if given the opportunity to learn about and engage in some of the conflicts within the discipline and we believe this would be true of students in the history of education as well. Education students should be given the opportunity to read and debate different accounts of educational policy and practice in the past and explore the implications of different understandings of educational history for current debates about work in the field.

Of course, these three elements for fostering engagement with the history of education - connections, construction, and conflict - are not separate ideas at all but intricately intertwined. For example, students who bring their own stories of schooling to class discussion will discover others whose experience is different and working through those conflicts will help develop a much fuller picture of education for the periods under consideration. Students engaged in the construction of history will discover its contingencies as they find gaps or contradictions in the available evidence. They will learn that historians necessarily regard their conclusions as being partial, tenuous, and open to reexamination in the light of new evidence. In other words, they will learn that contestation about the meaning of evidence and the conclusions that can be drawn from it are not a problem but an essential component of the nature of the discipline itself.

\section{References}

American Educational Research Association (2005). Executive summary. Studying teacher education: The report of the American Educational Research Association Panel on Research and Teacher Education (Eds.) M. Cochran-Smith and K. M. Zeichner). Mahwah, NJ: Lawrence Erlbaum Associates.

Bales, B. L. (2006). Teacher education policies in the United States: The accountability shift since 1980. Teaching and Teacher Education, 22, 395-407.

Barton, K. C., \& Levstik, L. S. (2004). Teaching history for the common good. Mahwah, NJ: Lawrence Erlbaum Associates.

Bartos, R. \& Souter, F. (1982). What are we teaching in educational foundations? Journal of Teacher Education, 33(2), 45-47.

Berlak, A. \& Berlak, H. (1981). Social change. London: Methuen.

Bondy, L. J. (1938, October). The present situation in modern languages in our schools, The School, 120-122.

Bowers, H (1939, October). Guesswork. The School, 97-98. 
Bruner, J. (1960). The process of education. Boston, MA: Harvard University Press.

Bruno-Jofré, R. \& Steiner, K. (2007). Fostering educative experiences in virtual high school history. Encounters on Education, 8, 69-82.

Butin, D. W. (2004). The foundations of preparing teachers: Are education schools really "intellectually barren" and "ideological?" Teachers College Record Online. Retrieved from http://www.tcrecord.org/content.asp?contentid=11349

Christou, T. (2010). Reflecting from the margins of education faculties: Refiguring the humanist, and finding a space for story in history. Brock Education, 20(1), 49-63.

Christou, T. (2009). Gone but not forgotten: The decline of history as an educational foundation. Journal of Curriculum Studies, 41(5), 569-583.

Christou, T., \& Sears, A. (2010, Winter). Rapprochement: Toward an inclusive approach to history and citizenship education in Canada. Canadian Issues/Thèmes Canadiens, 17-21.

Clark, A. (2008). History's children: History wars in the classroom. Sydney: University of New South Wales Press.

Clark, A. (2009). Teaching the nation's story: Comparing public debates and classroom perspectives of history education in Australia and Canada. Journal of Curriculum Studies, 41(6), 745-762.

Clark, P. (Ed.). (2011). New possibilities for the past: Shaping history education in Canada. Vancouver: University of British Columbia Press.

Crittenden, B. S. (1989). Some prior questions. In D. Myers \& F. Reid (Eds.) Educating teachers: Critiques and proposals (pp. 9-26). Toronto: Institute for Studies in Education.

Davis, O. L. (1992). Memory, our educational practice, and history. Educational Forum, 56, 375-379.

Dewey, J. (1916). Democracy and education. New York: Macmillan.

Dewey, J. (1929). The sources of a science of education. New York: Horace Liveright.

Dewey, J. (1966). Lectures in the philosophy of education: 1899. New York: Random House.

Dewhurst, D. \& Lamb, S. (2005). Educational stories: Engaging teachers in educational theory. Educational Philosophy and Theory, 37(6), 907-917.

Eco, U. (2004). The mysterious flame of Queen Loana. Orlando: Harcourt, Inc.

Egan, K. (1983). Social studies and the erosion of education. Curriculum Inquiry, 13(2), $195-214$

Engle, S. H. (1986). Late night thoughts about the new social studies. Social Education, 50(1), 20-22.

Evans, C. S. (1987). Teaching a global perspective in elementary classrooms. Elementary School Journal, 87(5), 544-555.

Fenton, E. (1967). The new social studies. New York: Holt, Rinehart and Winston.

Fischer, D. H. (1970). Historians' fallacies: Toward a logic of historical thought. New York: Harper Torchbooks.

Freeman, D. (1994). The use of language data in the study of teachers' knowledge. In I.Carlgren, G. Handal, \& S. Vaage (Eds.),_Teachers' minds and actions (pp. 77-92). London: The Falmer Press.

Freiberg, H. J. \& Waxman, H.C. (1990). Changing teacher education. In R.W. Houston (Ed.), Handbook of research on teacher education (pp. 717-635). New York: Macmillan.

Fullan, M. G., Connelly, F.M., et al. (1990). Teacher education in Ontario: Current practices and options for the future. Kingston: Queen's Printer for Ontario.

Fyfe, W. H. (1934, April). Science in secondary education. The School, 653-654.

Garrett, A. W. (1994). What is curriculum history and why is it important? American Educational Studies Association. Retrieved from http://www.eric.ed.gov:80/PDFS/ ED383584.pdf.

Grimmett, P. P., MacKinnon, A.M. et al. (1990). Reflective practice in teacher education. In R. T. Clift, R. Houston, \& N. Pugash (Eds.), Encouraging reflective practice (pp. 20-38). New York: Teachers College Press. 
Hargreaves, A. (2003). Teaching in the knowledge society: Education in the age of insecurity. New York: Teachers College Press.

Hess, F. M. (2010). The same thing over and over: How school reformers get stuck in yesterday's ideas. Cambridge, MA: Harvard University Press.

Howe, E. M. (2009). Henry David Thoreau, forest succession and the nature of science: A method for curriculum development. American Biology Teacher, 71(7), 397-404.

Hyslop-Margison, E. J., \& Sears, A. (2010). Enhancing teacher performance: The role of professional autonomy. Interchange, 41(1), 1-15.

Jankvist, U. (2009). A categorization of the "whys" and "hows" of using history in mathematics education. Educational Studies in Mathematics, 71(3), 235-261.

Kennedy, K. J. (2005). Rethinking teachers' professional responsibilities: Towards a civic professionalism. International Journal of Citizenship and Teacher Education, 1(1), 3-15.

Kliebard, H. M. (1992). Forging the American curriculum: Essays in curriculum history and theory. London: Routledge.

Kliebard, H. M. (1995). Why history of education? The Journal of Educational Research 88(4), 194-199.

Lagemann, E. C. (2005). Does history matter in educational research? A brief for the humanities in the age of science. Harvard Educational Review 75(1), 9-24.

Lévesque, S. (2008). Thinking historically: Educating students for the twenty-first century. Toronto: University of Toronto Press.

Levine, A. (2005). Educating school leaders. New York: The Education Schools Project.

Levstik, L. S., \& Barton, K. (2008). Researching history education. New York: Routledge.

Lewis E. (1939, October). What pupils think of the activity programme, The School, 100-101.

Liddy, R. B. (1934, June) The school as a factor in the making of the mind. The School, 232-233.

MacDonald, J. B. (1982). How literal is curriculum theory? Theory into Practice 21(1), 55-61.

MacKinnon, A. M. \& Erickson, G.G. (1992). The roles of reflective practice and foundational disciplines in teacher education. In T. Russell \& H. Munby (Eds.), Teachers and teaching: From classroom to reflection (pp. 192-210). London: Falmer Press.

Mark, C. E. (1940, March). Some educational pitfalls. The School, 562-564.

Matthews, M. R. (1997). Scheffler revisited on the role of history and philosophy of science in science teacher education. Studies in Philosophy and Education, 16(1). 159-173.

Menand, L. (2010). The marketplace of ideas ( $1^{\text {st }} \mathrm{ed}$.). New York: W.W. Norton.

Myers, D. \& Saul, D. (1989). How not to reform a teacher education system: Ontario 1966-1971. In D. Myers \& F. Reid (Eds.), Educating teachers: Critiques and proposals. Toronto: Ontario Institute for Studies in Education.

National Research Council (2002). Scientific research in education. Washington: National Academy Press.

Nussbaum, M. C. (2010). Not for profit: Why democracy needs the humanities. Princeton, NJ: Princeton University Press.

Osborne, K. (2001). Review of the books Knowing, teaching and learning history, P. Stearns, P. Seixas, \& S. Weinburg (Eds.). (2000), New York University Press and L'histoire à l' école: Matière à penser, Robert Martineau (1999), Paris/Montreal: L' Harmattan, The Canadian Historical Review, 82(3), 548-555.

Osborne, K. (2011). Teaching Canadian history: A century of debate. In P. Clark (Ed.), History teaching and learning in Canada: A state of the art look (pp. 55-80). Vancouver : UBC Press.

Province of New Brunswick. (n.d.). 21st century standards of practice for beginning teachers in New Brunswick. Fredericton, NB: Province of New Brunswick.

Queen's University. (1907). Preliminary announcement of the Faculty of Education. Kingston, ON: Queen's University. 
Queen's University. (1914). Faculty of Education: Annual calendar, 1914-1915. Kingston. ON: Queen's University.

Queen's University. (1917). Faculty of Education: Annual calendar, 1917-1918. Kingston, ON: Queen's University.

Queen's University. (1919). Faculty of Education: Annual calendar, 1919-1920. Kingston, ON: Queen's University.

Queen's University. (1968). McArthur College of Education: Annual calendar, 1968-1969. Kingston, ON: Queen's University.

Queen's University. (1970). McArthur College of Education: Annual calendar, 1969-1970. Kingston, ON: Queen's University.

Queen's University. (1971). The Faculty of Education: Calendar, 1971-1972. Kingston, ON: Queen's University.

Queen's University. (1972). The Faculty of Education: Calendar, 1972-1973. Kingston, ON: Queen's University.

Queen's University. (1973). The Faculty of Education: Calendar, 1973-1974. Kingston, ON: Queen's University.

Queen's University. (1974). The Faculty of Education: Calendar, 1974-1975. Kingston, ON: Queen's University.

Queen's University. (1979). Faculty of Education: Calendar, 1979-1980. Kingston, ON: Queen's University.

Queen's University. (1980). Faculty of Education: Calendar, 1980-1981. Kingston, ON: Queen's University.

Queen's University. (1981). The Faculty of Education: Calendar, 1981-1982. Kingston, ON: Queen's University.

Queen's University. (1983). The Faculty of Education: Calendar, 1983-1984. Kingston, ON: Queen's University.

Queen's University. (1985). The Faculty of Education: Calendar, 1985-1986. Kingston, ON: Queen's University.

Queen's University. (1991). The Faculty of Education: Calendar, 1991-1992. Kingston, ON: Queen's University.

Queen's University. (1993). The Faculty of Education: Calendar, 1993-1994. Kingston, ON: Queen's University.

Queen's University. (1994). The Faculty of Education: Calendar, 1994-1995. Kingston, ON: Queen's University.

Queen's University. (1995). The Faculty of Education: Calendar, 1995-1996. Kingston, ON: Queen's University.

Queen's University. (1996). The Faculty of Education: Calendar, 1996-1997. Kingston, ON: Queen's University.

Queen's University (1997). The Faculty of Education: Calendar, 1997-1998. Kingston, ON: Queen's University.

Queen's University. (2001). Faculty of Education: Calendar, 2001-2002. Kingston, ON: Queen's University.

Queen's University. (2006). Faculty of Education: Calendar, 2006-2007. Kingston, ON: Queen's University.

Rose, E. (2000). HyperTexts: The language and culture of educational computing. London, ON: The Althouse Press.

Sandwell, R. (2011). History is a verb: Teaching historical practice to teacher education Seudents. In P. Clark (Ed.), New possibilities for the past: Shaping history education in Canada (pp. 224-244). Vancouver: UBC Press.

Schön, D. (1983). The reflective practitioner: How professionals think in action. New York: Basic Books.

Schön, D. (1987). Educating the reflective practitioner: Toward a new design for teaching and learning in the professions. San Francisco: Jossey-Bass. 
Sears, A. (2003). Retooling the mind factory: Education in a lean state. Aurora, ON: Garamond Press.

Seixas, P. (2004). Theorizing historical consciousness. Toronto: University of Toronto Press.

Smitheram, V. \& Hillis, E.S. (1989). Avoiding guaranteed failure. In D. Myers \& F. Reid (Eds.), Educating teachers: Critiques and proposals (pp. 52-68). Toronto: Ontario Institute for Studies in Education.

Spencer, H. (1860). Education: Intellectual, moral and physical. New York: D. Appleton and Company.

Spring, J. (1994). The American school 1642-1993. New York: McGraw-Hill.

The Canadian School Journal (1934, February). Editorial: Fads and frills in education, 42-43.

The School (1934, January). Editorial notes: Looking backward, 370.

Tozer, S., Anderson, T.H. et al. (1990). Psychological and social foundations in teacher education: A thematic introduction. Teachers College Record 91(3), 293-299.

Tozer, S. \& McAninich, S. (1986). Social foundations of education in historical perspective. Educational Foundations, 1, 3-32.

Ungerleider, C. (1994). Power, politics, and the professionalization of teachers in British Columbia. In L. Erwin \& D. MacLennan (Eds.), Sociology of Education in Canada (pp. 370-379). Toronto: Copp Clark Longman.

Ungerleider, C. (2003). Failing our kids: How we are ruining our public schools. Toronto: McClelland \& Stewart.

Urban, W. J. (1990). Historical studies of teacher education. In W. R. Houston (Ed.), Handbook of research on teacher education: A project of the Association of Teacher Educators. New York: Macmillan Publishing Company.

Worley, V. \& Fry, P. (2002). Towards a philosophy of making teachers: Teacher training, education, preparation? Action in Teacher Education 24(3).

Zeichner, K. M. (1992). Conceptions of reflective teaching in contemporary U.S. teacher education program reforms. In L. Valli (Ed.), Reflective teacher education: Cases and critiques (pp. 161-173). Albany, NY: SUNY Press. 